\title{
Competitions in Physical Education Using Sports Education Model
}

\author{
Agi Ginanjar* \\ Department of Physical Education, Health and Recreation \\ STKIP Nahdlatul Ulama Indramayu \\ Indramayu, Indonesia \\ *agiginanjar@stkipnu.ac.id
}

\author{
Adang Suherman, Tite Juliantine, Yusuf Hidayat \\ Faculty of Sports and Health Education \\ Universitas Pendidikan Indonesia \\ Bandung, Indonesia
}

\begin{abstract}
The objective of this study is to provide an overview of the Sport Education Model in the process of learning physical education how to make the competition that can be beneficial for all students involved. The results of this study when the competition is given in the right way or can with the right learning model can provide a sense of security in the learning process.
\end{abstract} model

Keywords-competitive; physical education; sports education

\section{INTRODUCTION}

The winner of the competition may experience an increase in self-esteem so as to provide motivation to participate in subsequent competition activities [1]. The advantage of competition is to improve moral development, motivation, and prepare students in the real world; students prefer competition activities to build confidence and motivation [2,3]. Success and achievement orientation are a person's orientation towards the dominance of competitiveness to be able to move to a better way of life $[4,5]$, as of the value of competitive sports in schools is needed [6].

Physical education is suggested to promote student learning in the cognitive, psychomotor, and affective domains, the use of competitive activities as a learning experience is questionable. Competition can inhibit learning and give negative traits, such as cheating and violence [7]. Students who experience failure in competition experience a decrease in selfesteem and self-confidence, so that there is a decrease in motivation in learning $[1,2,7,8]$. In physical education competition activities can be said to be "zero-sum" where there are win and lose [9].

The negative consequences of competition can be eliminated if the competition is taught and used correctly in the class [10]. Physical education teachers need to think more about the children to develop learning programs [11]. Physical education teachers must provide a positive model in teaching students according to competition [11]. Furthermore, when taught appropriately, the competition provides a sense of security to support learning that is useful for students in the present and future [11]. Therefore, we need a concept or learning model that is suitable for competition activities. The teacher proposes an activity where students work together to complete a task. In assignments, each student is assigned a role that is determined to help complete the task. Throughout learning, students receive the same to practice the necessary skills and use game-like skills in gamelike [12].

Sport Education Model is a curriculum model that can be broadly expanded by schools to be used in various forms of sports [13]. Sport Education Model is a learning model that gives students a sport-based experience that is considered the most appropriate, both pedagogical and developmental in physical education. In the process, the Sport Education Model will give students all aspects needed to facilitate matches such as contract roles in a team, match rules, scoring, referees, etc. [13]. Students involved in Sport Education Model will become literate, enthusiastic and competent sports people through the six characteristics of Sport Education Model, namely: Seasons, Affiliation, Formal Competition, Culminating Event, Keeping Records, and Festivity [13]. Sport Education Model is designed to provide children with appropriate competition [14].

This study aims to provide an overview of the Sport Education Model in the process of learning physical education how to make the competition that can be beneficial for all students involved. Sport Education Model Planning.

\section{METHOD}

The method uses literature study by reviewing 9 articles and 5 books. The results of this literature review will be used to identify literature related to Sport Education Model and competitive.

\section{Result AND Discussion}

\section{A. Sport Education Model Planning}

In the selection of sports tailored to the knowledge of the sport to be chosen. In addition, you must also choose sports that are familiar or often used because it will also facilitate skills and knowledge for the role of referees, score takers, statistics, etc. [13]. This is useful for affiliates so that students are more enthusiastic in carrying out the learning process by using Sport Education Models not to let teachers choose sports that students do not know.

Student involvement is the division of the role of each student with responsibility and usually, the role is in 
accordance with what is in the title of a sports competition such as a player, coach, manager, referee, match registrar, etc. [13]. This is useful so that students have responsibilities according to the role they get. It would be better to generate competitiveness by giving awards from each role that is obtained, but it must be based on the process obtained by students and students to be reminded that each process will get an award not only awarding at the end of the course.

In addition to the selection of team members, every student who has become a member of one team must maintain the consistency of the student until the Sport Education Model season ends. For this reason, it is better for us to do team selection so that the team has the same strength. This can be done by looking at the students' ability in the chosen sport, with the teacher pointing out fairly in each team member, and can by making test skills first to rank students for team selection [13]. This is useful for maintaining team strength in the competition. Do not let a team be occupied by all students who have good skills because it will give the view of this team will win the match so that the other teams feel there is no need to seriously follow the learning process. Remember that the process of each individual in the Sport Education Model will get an award not just to be a champion.

Identifying and preparing materials is a requirement that will assist in the smooth process of the program. The material in question is like a contract for each role, competition schedule, a match sheet, match rules, etc. [13]. Make the best possible planning this will have an impact on students' boredom following the learning process. If we have a process that is good from the beginning to the end of the learning students will be motivated because they will know what they will do each meeting so that students in the future team will display the best both in the process or in the match to be held.

In running the season, make each team choose the name and uniform to be used, make a team banner or flag, create a team profile, make a strategic publication every time, at the end of the season ending with a list of goal scorers, best players, best teams, etc. [13]. Making team names, uniforms, profiles, and team banners is useful so that students become more motivated in carrying out the learning process. As for the end of the season with a list of goal scorers, best players, best teams, etc. to motivate students that in the process carried out by each student has a goal. Although the main purpose of the Sport Education Model is not just what is achieved at the end, but focused on remembering every process that goes through each student will get an award.

Good planning will certainly think about things that will interfere if the program does not run smoothly like rain, the field is used by other activities, or there is a national holiday [13]. Run according to what has been planned, because if one missed meeting will result in feelings of disappointment towards students. For example, if the student who is a trainer is ready with the training program that will be given and he has designed the exercise program two or three days ago, but when the learning process will take place it will be disturbing and the learning process will not occur.

From various research results stated that with a wide field allowing skilled students to dominate in matches, it can be overcome by modifying the game. Modifying the size of the field and the player will give students the opportunity to be involved in the chosen sport. Besides that, the rules and the duration of the game will also help in concentrating the intensity of the match to reduce wasted time [13]. This is useful so that each student participates in physical activity during the learning process. Suppose that in football in a team there are students who are skilled at playing football if using the field and too long match time allows the student to be able to selfmanoeuvres and score as many as possible and make students who are less skilled do not move and only rely on him.

\section{B. Recommendations for Competition Using Sport Education Models}

Avoid words that have winners and losers. Sport Education Model provides a format where victory is more than just printing more points than other teams. The aim is so that students have a clear understanding of all aspects of sports, rather than just having one perspective as a player. The teacher has a unique opportunity to produce lessons that foster positive student development. By focusing on student development, not the outcome of the game, the teacher can help students develop in an environment of achievement. Give awards in each activity that is carried out such as if students have difficulty working together as a team, emphasis can be placed on team affiliates. The teacher can reward the team that fulfils the purpose of working together in a positive way. Get to know each team and individual who achieves every achievement achieved can be displayed on a bulletin board. Don't let learning become too competitive. The expected focus is not the result but the process. Stay focused on the fundamental thing, namely, the learning process is not the results obtained. When it comes to coming still, it's still great. Have fun! [11].

\section{CONCLUSION}

With so many pros and cons in physical education related to sports competition. However, when the competition is given in the right way or can with the right learning model can provide a sense of security in the learning process.

\section{ACKNOWLEDGMENT}

The author thanks Prof. Dr. Adang Suherman, MA, Dr. Tite Juliantine, M.Pd, and Dr. Yusuf Hidayat, M. Si as a mentor in writing this article. Then the author expressed his love also to the ICSSHPE 2018 committee who gave the author the opportunity to publish this article.

\section{REFERENCES}

[1] H. Fait and J. Billing, Reassessment of the value of competition. In G. McGlyn (Ed.). Issues in physical education and sports, 1974.

[2] S.L. Greendorfer, "Psycho-Social Correlates of Organized Physical Activity," Journal of Physical Education, Recreation and Dance, vol. 58, no. 7, pp. 59-64, 1987.

[3] A. Kohn, No Contest: The Case Against Competition. Boston: Houghton Mifflin Company, 1986.

[4] T. Farshad, M. Jasem, and Mohammad, "Validation of an Instrument for Measuring Athletes ' Sport Orientation in Iranian Martial Artists 
Community," Middle-East Journal of Scientific Research, vol. 18, no. 6, pp. 738-743, 2013.

[5] M. Sheikh, J. Afshari, and H. Sheikh, "Comparing sport orientation between individuals and team sports and its relation to sport participation motivation," American Journal of Scientific Research, 2011.

[6] L. Almond, "Does competitive sport have educational validity in physical education?” In Science \& Sports, vol. 29, p. S51, 2014.

[7] L. Brown and S. Grineski, "Competition in Physical Education: An Educational Contradiction?" Journal of Physical Education, Recreation \& Dance, vol. 63, no. 1, pp. 17-77, 1992.

[8] D.N. Campbell, "On Being Number One: Competition in Education," Phi Delta Kappan, vol. 56, no. 2, pp. 143-146, 1974.

[9] J.U. Stein, "Competition: A Developmental Process," Journal of Physical Education, Recreation \& Dance, vol. 59, no. 3, pp. 30-32, 1988
[10] S. Grineski, "What is a truly developmentally appropriate physical education program for children?" Journal of Physical Education, Recreation \& Dance, vol. 63, no. 6, pp. 33-35, 1992.

[11] T.E. Layne, "Competition within Physical Education: Using Sport Education and Other Recommendations to Create a Productive, Competitive Environment," Strategies: A Journal for Physical and Sport Educators, vol. 27, no. 6, pp. 3-7, 2014.

[12] A.E. Jewett, L.L. Bain, and C.D. Ennis, The curriculum process in physical education (second edition). Madison: WCB Brown \& Benchmark, 1995.

[13] D. Siedentop, Sport education: quality PE through positive sport experiences. Champaign: Human Kinetics, 1994

[14] D. Siedentop, P.A. Hastie, and Hans van der Mars, Complete Guide to Sport Education. Champaign: Human Kinetics. Retrieved from www.HumanKinetics.com, 2011. 